\title{
Quantification of the Role of Integrated Pest Management (IPM) against Brown Planthopper Nilaparvata lugens Stål. in the Upland Rainfed Rice Growing Areas of West Bengal, India
}

\author{
Pinaki Acharjee $^{1 *}$, Chitta Ranjan Satpathi $^{1}$, Sanjit Pramanik ${ }^{2}$ and Malay Kanti Modak ${ }^{3}$ \\ ${ }^{1}$ Department of Agricultural Entomology, ${ }^{2}$ Department of Soil Water and Conservation, \\ Bidhan Chandra Krishi Viswavidyalaya, Mohanpur Nadia, West Bengal, 741252, India \\ ${ }^{3}$ Dept. of Seed Science and Technology, Institute of Agricultural Science, Calcutta University, \\ Kolkata, West Bengal, 700019, India \\ *Corresponding author
}

A B S T R A C T

K e y w o r d s
Brown plant
hopper, Rice,
I.P.M, Crop age
Article Info
$\begin{aligned} & \text { Accepted: } \\ & 22 \text { July } 2020 \\ & \text { Available Online: } \\ & 10 \text { August } 2020\end{aligned}$

\begin{abstract}
A field trial was conducted to quantify the role of Integrated Pest management (IPM) against brown planthopper Nilaparvata lugens Stål. in the upland rainfed rice growing areas of West Bengal, India during 2002-03 and it was reevaluated during 2017-18. The trail comprised of three treatments viz. (a) Natural Biological Control (NBC) -with no application of insecticides throughout the crop growth (b) Schedule based protection (SBP)- application pesticides as per farmers recommendation (C) IPM Treatment- selected component of management at two different villages in the district of Bankura and Birbhum. The pooled data from the corresponding years $(2002,2017$ and 2003, 2018) of the seasons indicated that among the three treatments the Integrated Pest Management system which included cultivation of resistant variety viz., Chaityanya (MTU-2067), delaying of planting time up to first week of August, application of fertilizer @ 60:40:40 $(\mathrm{N}: \mathrm{P}: \mathrm{K})$ with spacing $20 \times 15 \mathrm{~cm}$, alternate wetting and drying the field at 80,87 and 94 DAT, and spraying of Imidachloprid 17.8 SL @ 30 gm a.i. / ha at 75 and 90 DAT could maintain the BPH population below economic threshold level in upland rainfed rice growing areas of West Bengal.
\end{abstract}

\section{Introduction}

In India, the first IPM programme in rice crop was started at Cuttack in 1975. As a result of implementation of a number of cultural practices and Economic Threshold Level
(ETL) based application of insecticides, the number of applications was reduced from 3-4 to one (Brader, 1979). Subsequently, an Operational Research Project (OPR) was initiated on integrated control of Brown Plant Hopper $(\mathrm{BPH})$ in other parts of India. This 
also led to a reduction in number of sprays simultaneously increased yields of rice (Krishnaiah, 1983). Due to problem of residual toxicity, bio accumulation and biomagnifications of toxic residues, increasing tolerance, disturbances in ecosystem, prohibitive costs in chemical method, increasing emphasis has been given on IPM approaches particularly in last two decades. But adoption of the approach at farmers level in developing Countries like India is still far from satisfactory (Kalode and Krishnaiah, 1991). From the study of the Incidence of Brown Planthopper (BPH) Nilaparvata lugens Stål (Delphacidae: Hemiptera) in relation to the age of rice crop it was recorded that the 100-140 days old aged rice plant harbored higher number of BPH/hill compared to 80-90 days old crop (Shivshankar et al., 2012). Farmers are mostly rely on Chemicals pesticides for the management of rice pest. But the evaluation of Some Insecticides Against Brown Plant hopper, Nilaparvata lugens (Stål) in rice showed that basal application of Fipronil 0.3 G@ 25 kg ha-1 was made once at 25 DAT followed by Imidachloprid 40+Ethiprole 40\% w/w or Glamore 80 WG @ $100 \mathrm{~g}$ a.i. ha-1; at 55 DAT and 65 DAT are effective for controlling brown plant hopper in Chiplima, Sambalpur, Odisha, India. It is thus evident that despite efforts to develop suitable IPM programmed in the last few years, $\mathrm{BPH}$ has continued to be the major pest in West Bengal as given in Fig. 1.

\section{Materials and Methods}

Field trials were conducted during the kharif season of 2002 to 03 at two different villages Viz. Gorabari: district Bankura; and Gopalpur: district Birbhum. The trail comprised of three treatment Viz. (a) Natural Biological Control (NBC) -with no application of insecticides throughout the crop growth (b) Schedule based protection (SBP)- application of Fipronil $0.3 \mathrm{G} @ 25 \mathrm{~kg}$ a.i./ha at nursery \& transplanted field at 25 DAT, application of Imidacloprid @30 gm a.i. at 60 to $70 \& 80$ to 90 DAT. (C) IPM Treatmentselected component of Management Viz. cultivation of resistant variety Chaityanya (MTU-2067) in rain fed up land areas (Gorabari and Kamalpur), delaying of planting time up to first week of August, application of fertilizer @ 60:40:40 (N:P:K) with spacing $20 \times 15 \mathrm{~cm}$, alternate wetting and drying the field at 80,87 and 94 DAT, and spraying of Imidachloprid 17.8 SL @ 30 gm a.i. / ha at 75 to 90 DAT with 2 applications in each village. Each treatment covered an area of one hectare. Observations were recorded from 25 selected hills. Yield per hectare was computed from crop cuts of $5 \times 5 \mathrm{~m}$ area. The data were reevaluated after 15 years at the same location against brown planthopper during 2017-18.

The pooled data of 2002 and 2017 as well as 2003 and 2018 were subjected to analysis of variance after suitable transformation. Green yield and economy of different treatments were computed.

\section{Results and Discussion}

From the pooled data of 2002 and 2017 it is evident that at $60 \mathrm{DAT}$ the population of $\mathrm{BPH}$ was considerably low in the SBP treatment for both the sites at Gorabari (0.07 to 0.82 per hill) as compared to $\mathrm{NBC}(0.10$ to 3.40 per hill) and IPM treatments ( 0.10 to 2.22 insects hill). During both the succeeding years of study the population was mostly identical. The pooled data of 2003 and 2018 showed that it was 0.60 to $0.82,3.42$ to 3.62 and 0.82 to 2.22 hoppers per hill in SBP, NBC and IPM treatments respectively. In general the population build up started after 75 DAT. However, in the IPM treatment the BPH population (1.72 to 2.52 insects per hill) could not reach beyond the economic Threshold 
level which was significantly lower than the NBC treatments (2.52 to 8.50 per hill) at Gorabari (Table 1). The population level obtained from the analysis of pooled data during 2003 and 2018 indicated that the IPM treatment was also significantly lower (1.40 to 1.42 insects per hill) than both NBC (8.42 to 12.21 insects hill) and SBP treatments (1.62 to 3.02 insects per hill) respectively at Gorabari (Table 2). Although the peak BPH population at $90 \mathrm{DAT}$ was 32.38 to 95.21 and 4.02 to 35.52 insects per hill in the NBC and SBP respectively treatments but the population in the IPM treatment remained below the Economic thresh hold Level (2.52 to 4.62 insects per hill) at Gorabari during first season of study. Due to some favorable weather conditions the population increased in 2003 and it was observed that pooled data were higher as compare to first season as 34.42 to $111.21,4.42$ to 50.21 and 4.62 to 5.80 insects / hill in NBC, SBP \& IPM Treatment respectively (Table 2). Although the population emigrated after 120 DAT, a significantly lower population was observed in the IPM treatments during first year of both the seasons (2002 and 2017) and subsequent years (2003 and 2018) of study (Table 1\&2).

The pooled data of 2002 and 2017 from another village (Gopalpur) under rain fed upland areas of West Bengal showed that there was no significant difference in BPH population among the treatments at 60 DAT (Table 3) but the pooled data from the corresponding years of the seasons, 2003 and 2018 indicated that the population in the IPM treatment was significantly lower than the SBP \& NBC (Table 4). At 75 DAT significant differences were observed among the treatments when the population was 2.52 to 9.12, 0.05 to 0.72 and 2.02 to 2.45 insects per hill during 2002 and 2017. Whereas it was 7.22 to $9.22,2.62$ to $0.82,0.52$ to 2.32 insects per hill during 2003 and 2018 in the NBC, SBP \& IPM treatments respectively.

Table.1 Quantification of relative importance of brown plant hopper Nilaparvata lugens Stål. as influenced by different treatments in Gorabari (Bankura)

\section{Treatment}

DAT
Pooled data of Kharif 2002 and 2017

Average number of plant hopper Nilaparvara lugens Stål. Per hill at different

\begin{tabular}{|c|c|c|c|c|c|c|c|c|c|c|c|c|}
\hline & \multicolumn{12}{|l|}{ DAT } \\
\hline & \multicolumn{3}{|c|}{60 DAT } & \multicolumn{3}{|c|}{75 DAT } & \multicolumn{3}{|c|}{90 DAT } & \multicolumn{3}{|c|}{120 DAT } \\
\hline & Site 1 & Site 2 & Mean & Site 1 & Site 2 & Mean & Site 1 & Site 2 & Mean & Site 1 & Site 2 & Mean \\
\hline NBC & $\begin{array}{c}0.10 \\
(0.77)\end{array}$ & $\begin{array}{l}3.40 \\
(1.97)\end{array}$ & $\begin{array}{l}1.75 \\
(1.5)\end{array}$ & $\begin{array}{l}2.52 \\
(1.73)\end{array}$ & $\begin{array}{l}8.50 \\
(3.00)\end{array}$ & $\begin{array}{l}5.51 \\
(2.45)\end{array}$ & $\begin{array}{l}95.21 \\
(9.78)\end{array}$ & $\begin{array}{l}32.38 \\
(5.73)\end{array}$ & $\begin{array}{l}63.79 \\
(8.01)\end{array}$ & $\begin{array}{l}12.22 \\
(3.57)\end{array}$ & $\begin{array}{l}12.32 \\
(3.58)\end{array}$ & $\begin{array}{l}12.26 \\
(3.57)\end{array}$ \\
\hline SBP & $\begin{array}{c}0.07 \\
(0.75) \\
\end{array}$ & $\begin{array}{l}0.82 \\
(1.14) \\
\end{array}$ & $\begin{array}{l}0.47 \\
(0.98)\end{array}$ & $\begin{array}{l}0.52 \\
(1.00)\end{array}$ & $\begin{array}{l}1.32 \\
(1.34)\end{array}$ & $\begin{array}{l}0.92 \\
(1.19)\end{array}$ & $\begin{array}{l}32.52 \\
(5.74)\end{array}$ & $\begin{array}{l}4.02 \\
(2.12)\end{array}$ & $\begin{array}{l}18.27 \\
(4.33)\end{array}$ & $\begin{array}{l}3.14 \\
(1.90)\end{array}$ & $\begin{array}{l}3.12 \\
(1.90)\end{array}$ & $\begin{array}{l}3.12 \\
(1.90)\end{array}$ \\
\hline IPM & $\begin{array}{c}0.10 \\
(0.77)\end{array}$ & $\begin{array}{l}2.22 \\
(1.64)\end{array}$ & $\begin{array}{l}1.16 \\
(1.28)\end{array}$ & $\begin{array}{l}2.52 \\
(1.73)\end{array}$ & $\begin{array}{l}1.72 \\
(1.48)\end{array}$ & $\begin{array}{l}2.12 \\
(1.61)\end{array}$ & $\begin{array}{l}2.52 \\
(1.73)\end{array}$ & $\begin{array}{l}4.62 \\
(2.26)\end{array}$ & $\begin{array}{l}3.57 \\
(2.01)\end{array}$ & $\begin{array}{l}3.16 \\
(1.19)\end{array}$ & $\begin{array}{l}3.12 \\
(1.90)\end{array}$ & $\begin{array}{l}3.14 \\
(1.90)\end{array}$ \\
\hline CD5\% & 0.3698 & 0.1279 & & 0.2179 & 0.2179 & & 0.126 & 0.2494 & & 0.2516 & 0.2179 & \\
\hline S.Em \pm & 0.1200 & 0.0707 & & 0.0707 & 0.0707 & & 0.0701 & 0.0787 & & 0.0816 & 0.0707 & \\
\hline
\end{tabular}

NBC- Natural Biological Control, SBP -Schedule Based Protection, IPM - Integrated Pest Management

Figures in Parenthesis indicate Square root transformed values $\quad(\sqrt{n+0.5})$

DAT - Day After Transplanting. 
Table.2 Quantification of relative importance of brown plant hopper Nilaparvata lugens StaI. as influenced by different treatments in Gorabari (Bankura)

\begin{tabular}{|c|c|c|c|c|c|c|c|c|c|c|c|c|}
\hline \multirow[t]{3}{*}{$\begin{array}{c}\text { Treatme } \\
\text { nt }\end{array}$} & \multicolumn{12}{|c|}{$\begin{array}{l}\text { Pooled data of Kharif } 2003 \text { and } 2018 \\
\text { Average number of plant hopper Nilaparvara lugens Stål. Per hill at different }\end{array}$} \\
\hline & \multicolumn{3}{|c|}{60 DAT } & \multicolumn{3}{|c|}{75 DAT } & \multicolumn{3}{|c|}{90 DAT } & \multicolumn{3}{|c|}{120 DAT } \\
\hline & Site 1 & Site 2 & Mean & Site 1 & Site 2 & Mean & Site 1 & Site 2 & Mean & Site 1 & Site 2 & Mean \\
\hline NBC & $\begin{array}{c}3.60 \\
(2.20)\end{array}$ & $\begin{array}{c}3.42 \\
(1.97)\end{array}$ & $\begin{array}{c}3.51 \\
(2.00)\end{array}$ & $\begin{array}{l}12.21 \\
(3.56)\end{array}$ & $\begin{array}{c}8.42 \\
(2.98)\end{array}$ & $\begin{array}{l}10.32 \\
(3.28)\end{array}$ & $\begin{array}{l}111.21 \\
(10.56)\end{array}$ & $\begin{array}{l}32.42 \\
(5.73)\end{array}$ & $\begin{array}{c}71.81 \\
8.50\end{array}$ & $\begin{array}{c}75.2 \\
(8.70)\end{array}$ & $\begin{array}{l}11.80 \\
(3.50)\end{array}$ & $\begin{array}{c}43.5 \\
(6.63)\end{array}$ \\
\hline SBP & $\begin{array}{c}0.60 \\
(1.40)\end{array}$ & $\begin{array}{c}0.82 \\
(1.14)\end{array}$ & $\begin{array}{l}0.71 \\
(1.1)\end{array}$ & $\begin{array}{c}3.02 \\
(1.87)\end{array}$ & $\begin{array}{c}1.62 \\
(1.45)\end{array}$ & $\begin{array}{c}2.32 \\
(1.67)\end{array}$ & $\begin{array}{l}50.21 \\
(7.12)\end{array}$ & $\begin{array}{c}4.42 \\
(2.21)\end{array}$ & $\begin{array}{l}27.31 \\
(5.27)\end{array}$ & $\begin{array}{l}35.44 \\
(5.99)\end{array}$ & $\begin{array}{c}3.2 \\
(1.92)\end{array}$ & $\begin{array}{l}19.32 \\
(4.45)\end{array}$ \\
\hline IPM & $\begin{array}{c}0.82 \\
(1.14)\end{array}$ & $\begin{array}{c}2.22 \\
(1.64)\end{array}$ & $\begin{array}{c}1.52 \\
(1.42)\end{array}$ & $\begin{array}{c}1.40 \\
(1.37)\end{array}$ & $\begin{array}{c}1.42 \\
(1.38)\end{array}$ & $\begin{array}{c}1.41 \\
(1.38)\end{array}$ & $\begin{array}{c}5.80 \\
(2.50)\end{array}$ & $\begin{array}{c}4.62 \\
(2.26)\end{array}$ & $\begin{array}{c}5.21 \\
(2.38)\end{array}$ & $\begin{array}{c}4.60 \\
(2.25)\end{array}$ & $\begin{array}{c}3.2 \\
(1.92)\end{array}$ & $\begin{array}{c}3.9 \\
(2.09)\end{array}$ \\
\hline CD5\% & 0.3873 & 0.2179 & & 0.2179 & 0.2179 & & 0.2238 & 0.2178 & & 0.3490 & 0.2179 & \\
\hline S.Em \pm & 0.1257 & 0.0707 & & 0.0707 & & & 0.0726 & 0.0707 & & 0.113 & 0.0707 & \\
\hline
\end{tabular}

NBC- Natural Biological Control, SBP -Schedule Based Protection, IPM - Integrated Pest Management

Figures in Parenthesis indicate Square root transformed values $(\sqrt{n+0.5})$

DAT - Day After Transplanting.

Table.3 Quantification of relative importance of brown plant hopper Nilaparvata lugens StaI. as influenced by different treatments in Gopalpur (Birbhum)

\begin{tabular}{|c|c|c|c|c|c|c|c|c|c|c|c|c|}
\hline \multirow[t]{3}{*}{ Treatment } & \multicolumn{12}{|c|}{$\begin{array}{c}\text { Pooled data of Kharif } 2002 \text { and } 2017 \\
\text { Average number of plant hopper Nilaparvara lugens Stål. Per hill at different } \\
\text { DAT }\end{array}$} \\
\hline & \multicolumn{3}{|c|}{60 DAT } & \multicolumn{3}{|c|}{75 DAT } & \multicolumn{3}{|c|}{90 DAT } & \multicolumn{3}{|c|}{120 DAT } \\
\hline & Site 1 & Site 2 & Mean & Site 1 & Site 2 & Mean & Site 1 & Site 2 & Mean & Site 1 & Site 2 & Mean \\
\hline NBC & $\begin{array}{c}0.15 \\
(0.80)\end{array}$ & $\begin{array}{l}0.32 \\
(0.90)\end{array}$ & $\begin{array}{l}0.23 \\
(0.85)\end{array}$ & $\begin{array}{l}2.52 \\
(1.73)\end{array}$ & $\begin{array}{l}9.12 \\
(3.10)\end{array}$ & $\begin{array}{l}5.82 \\
(2.51)\end{array}$ & $\begin{array}{l}238.21 \\
(15.45)\end{array}$ & $\begin{array}{l}31.42 \\
(5.64)\end{array}$ & $\begin{array}{l}134.81 \\
(11.63)\end{array}$ & $\begin{array}{l}12.24 \\
(3.56)\end{array}$ & $\begin{array}{l}12.22 \\
(3.56)\end{array}$ & $\begin{array}{l}12.23 \\
(3.56)\end{array}$ \\
\hline SBP & $\begin{array}{c}0.05 \\
(0.74)\end{array}$ & $\begin{array}{l}0.32 \\
(0.90)\end{array}$ & $\begin{array}{l}0.18 \\
(0.82)\end{array}$ & $\begin{array}{l}0.05 \\
(0.74)\end{array}$ & $\begin{array}{l}0.72 \\
(1.10)\end{array}$ & $\begin{array}{l}0.38 \\
(0.93)\end{array}$ & $\begin{array}{l}45.54 \\
(6.78)\end{array}$ & $\begin{array}{l}4.42 \\
(2.21)\end{array}$ & $\begin{array}{l}24.97 \\
(5.04)\end{array}$ & $\begin{array}{l}3.9 \\
(2.09)\end{array}$ & $\begin{array}{l}3.82 \\
(2.07)\end{array}$ & $\begin{array}{l}3.86 \\
(2.08)\end{array}$ \\
\hline IPM & $\begin{array}{c}0.09 \\
(0.76)\end{array}$ & $\begin{array}{l}0.42 \\
(0.95)\end{array}$ & $\begin{array}{l}0.21 \\
(0.84)\end{array}$ & $\begin{array}{l}2.45 \\
(1.71)\end{array}$ & $\begin{array}{l}2.02 \\
(1.58)\end{array}$ & $\begin{array}{l}2.23 \\
(1.65)\end{array}$ & $\begin{array}{l}6.12 \\
(2.56)\end{array}$ & $\begin{array}{l}4.82 \\
(2.30)\end{array}$ & $\begin{array}{l}5.47 \\
(2.44)\end{array}$ & $\begin{array}{l}3.24 \\
(1.93)\end{array}$ & $\begin{array}{l}3.22 \\
(1.92)\end{array}$ & $\begin{array}{l}3.23 \\
(1.93)\end{array}$ \\
\hline CD5\% & NS & NS & & 0.1784 & 0.2179 & & 0.2224 & 0.2181 & & 0.2813 & 0.2179 & \\
\hline S.Em \pm & & & & 0.0579 & & & 0.0722 & 0.0708 & & 0.0913 & 0.0707 & \\
\hline
\end{tabular}

NBC- Natural Biological Control, SBP -Schedule Based Protection, IPM - Integrated Pest Management

Figures in Parenthesis indicate Square root transformed values $(\sqrt{n+0.5})$

DAT - Day After Transplanting. 
Table.4 Quantification of relative importance of brown plant hopper Nilaparvata lugens StaI. as influenced by different treatments in Gopalpur (Birbhum)

\begin{tabular}{|c|c|c|c|c|c|c|c|c|c|}
\hline \multirow[t]{3}{*}{ Treatment } & \multicolumn{9}{|c|}{$\begin{array}{c}\text { Pooled data of Kharif } 2003 \text { and } 2018 \\
\text { Average number of plant hopper Nilaparvara lugens Stål. Per hill at different } \\
\text { DAT }\end{array}$} \\
\hline & \multicolumn{3}{|c|}{60 DAT } & \multicolumn{3}{|c|}{75 DAT } & \multicolumn{3}{|c|}{90 DAT } \\
\hline & Site 1 & Site 2 & Mean & Site 1 & Site 2 & Mean & Site 1 & Site 2 & Mean \\
\hline NBC & $\begin{array}{c}2.62 \\
(1.76)\end{array}$ & $\begin{array}{l}3.42 \\
(1.97)\end{array}$ & $\begin{array}{l}3.02 \\
(1.87)\end{array}$ & $\begin{array}{l}7.22 \\
(2.77)\end{array}$ & $\begin{array}{l}9.22 \\
(3.11)\end{array}$ & $\begin{array}{l}8.22 \\
(2.95)\end{array}$ & $\begin{array}{l}54.00 \\
(7.38)\end{array}$ & $\begin{array}{l}10.46 \\
(3.26)\end{array}$ & $\begin{array}{l}32.23 \\
(5.72)\end{array}$ \\
\hline SBP & $\begin{array}{c}1.22 \\
(1.31)\end{array}$ & $\begin{array}{l}1.02 \\
(1.23)\end{array}$ & $\begin{array}{l}1.12 \\
(1.27)\end{array}$ & $\begin{array}{l}2.62 \\
(1.76)\end{array}$ & $\begin{array}{l}0.82 \\
(1.14)\end{array}$ & $\begin{array}{l}1.72 \\
(1.48)\end{array}$ & $\begin{array}{l}16.00 \\
(0.06)\end{array}$ & $\begin{array}{l}3.47 \\
(1.99)\end{array}$ & $\begin{array}{l}9.73 \\
(3.19)\end{array}$ \\
\hline IPM & $\begin{array}{c}0.32 \\
(0.99)\end{array}$ & $\begin{array}{l}2.42 \\
(2.21)\end{array}$ & $\begin{array}{l}1.37 \\
(1.36)\end{array}$ & $\begin{array}{l}0.52 \\
(1.00)\end{array}$ & $\begin{array}{l}2.32 \\
(1.67)\end{array}$ & $\begin{array}{l}1.42 \\
(1.38)\end{array}$ & $\begin{array}{l}5.80 \\
(2.50)\end{array}$ & $\begin{array}{l}3.22 \\
(1.99)\end{array}$ & $\begin{array}{l}4.51 \\
(2.23)\end{array}$ \\
\hline CD5\% & 0.242 & 0.2179 & & 0.2179 & 0.2179 & & 0.2182 & 3.49 & \\
\hline S.Em \pm & 0.0787 & 0.0707 & & 0.0707 & 0.0707 & & 0.0708 & 1.29 & \\
\hline
\end{tabular}

NBC- Natural Biological Control, SBP -Schedule Based Protection, IPM - Integrated Pest Management

Figures in Parenthesis indicate Square root transformed values $(\sqrt{n+0.5})$

DAT - Day After Transplanting.

Fig.1 (a) Brown plant hopper colony on rice stem and its (b) hopper burn symptom at Gopalpur, Birbhum during kharif (rainy) 2017

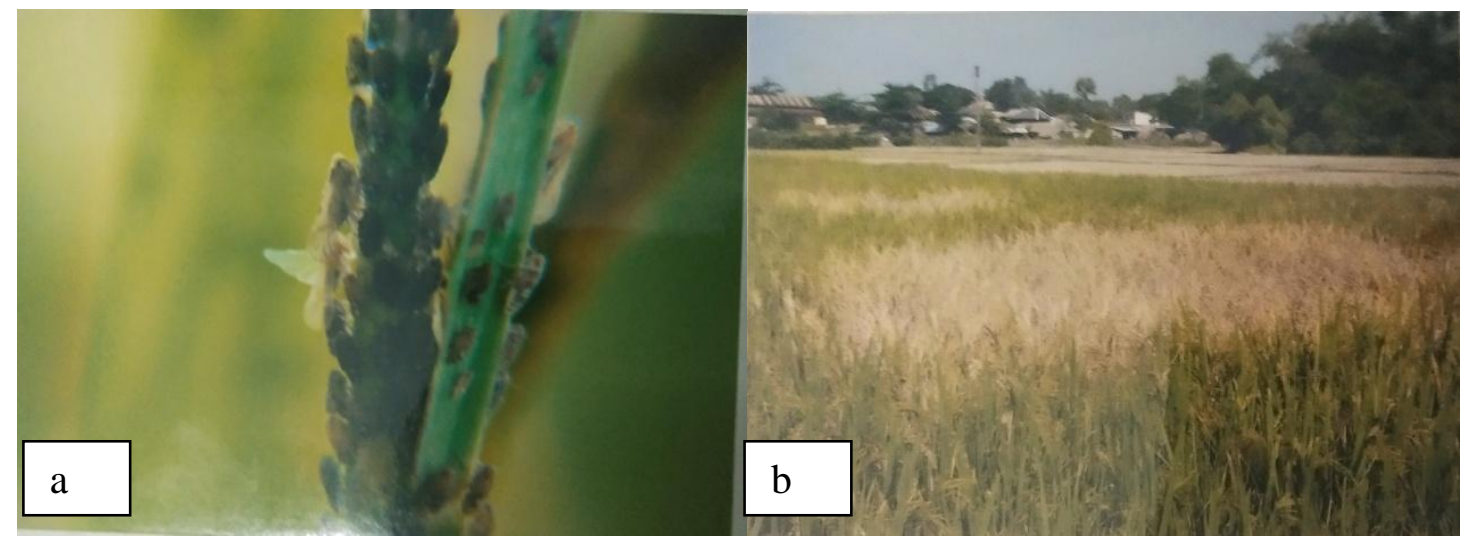

Despite application of suitable control measure a substantial level of population was recorded in the IPM (4.82 to 6.82 insects per hill) and SBP (4.42 to 45.52 insects per hill) treatments which were significantly lower than the NBC treatment (31.42 to 238.21insects per hill) at 90 DAT during the first phase of 2002 and 2017 (Table 3). The abrupt increase of $\mathrm{BPH}$ in upland areas was probably due to migration of the hoppers from the rice crop grown in nearby lowland areas. The population of $\mathrm{BPH}$ was drastically reduced after 90 DAT at Gopalpur in both 2003 and 2018 but the significant differences were observed among the treatments in which 10.16 to $54.00,3.47$ to $16.00,3.22$ to 5.88 insects per hill were recorded in NBC, SBP and IPM respectively (Table 4) with the onset 
of winter the $\mathrm{BPH}$ emigrated and at most similar level of population was maintained up to 120 DAT during first phase of study during 2002 and 2017. Heinrichs et al., (1979) recorded that the resistant varieties by and large will combine well with insecticides developed which may be a viable and meaningful system of IPM against BPH. Krishnaih (1983) reported that adoption of IPM practices brought down the general equilibrium potential of pest to much below the economic thresh hold level and thus BPH became a pest of no significance in the endemic areas. Josephet et al., (1999) reported that colossal loss in rice Yield due to BPH Outbreak in 1973 following indiscriminate pesticides use, but the loss could be revived through practices of IPM. Earlier Katti et al., (2001) recorded that low population of BPH was observed at Hyderabad during the kharif season of 1997. Their numbers were lowest in SBP (13.0 to 20.2 insect per 25 hill) Compared to NBP (17.6 to 41.8 insects per25 hills) and NBC (24.8 to 30.8 per 25 hills) during 60- 75 DAT Pasalu et al., (2005 also found that the population of BPH Were Significantly higher in farmers Practice (F.P) treatment (14.7 insect per hill) as compared to tae IPM (2.8 insect per hills) and scheduled treatment (S.B.P) (3.4 insect per hills) in rainfall rice growing area of west Bengal. Seni and Naik 2017 efficacy of Imidachloprid 40+Ethiprole $40 \%$ w/w against plant hoppers in both seasons, as it is recorded second highest mean percent reduction of hoppers over control. Ram 2010 also did some work on identification of new genes for brown plant hopper resistance in rice introgressed from $O$. glaberrima and O. minuta. Shivshankar 2012 studied the Incidence of brown planthopper (BPH) Nilaparvata lugens Stal. (Delphacidae: Hemiptera) in relation to age of the rice crop in Cauvery Command Area of Karnataka, India and recorded that the 100-140 days old aged rice plant harbored higher number of
$\mathrm{BPH} /$ hill compared to 80-90 days old crop

Summary and conclusion are as follows:

From this study it is emerged out that among the three treatments the Integrated Pest Management system which included cultivation of resistant variety viz., Chaityanya (MTU-2067), delaying of planting time up to first week of August, application of fertilizer@60:40:40 (N:P:K) with spacing $20 \times 15 \mathrm{~cm}$, alternate wetting and drying the field at 80,87 and 94 DAT, and spraying of Imidachloprid 17.8 SL @ 30 gm a.i. / ha at 75 and 90 DAT could maintain the BPH population below economic threshold level in upland rain fed rice growing areas of West Bengal.

\section{References}

Brader, L. 1979 Integrated Pest control intac developing world. A. Rev. Ent., 24: 225-254.

Heinrichs, E.A., Saxena, R.C., and Chelliah, S. 1979. Development and Implementation of insect Pest Management System for rice in tropical Asia. In: Sensible Use of Pesticides FFTC Ser No. 14. ASPAC, Taiwan pp, 208-249.

Joseph, D., Krishnakumari, Amma, Nair, K., Girija, D., and Thomas, B., 1999, Operational Research Project on Integrated Control of rice Pests in Kuttanad Five Decades of Rice Research. Kerala Agricultural University. 81-88.

Kalode, M.B and Krichraich, K. 1991, International Pest Management in Rice. Indian J. Plant Prot 19:117-132.

Katti, Gururaj, Pasalu, I.C, Varma, N.R.G and Dhanda Pani, N. 2001. Quantification of Natural Biological Control in rice ecosystem for possible exploitation in rice IPM. Indian J. Ent 63(4):439-448. 
Krishnaial, K. 1983. Integrated pest management in rice, paper Presented in rice workshop. Hyderabad, April, 912, 1983.

Pasalu I.C; Katti Gururaj, Dari, R. C; Bora, D.K., Singl, M.P, Satpathi, C. R; Reddy, P.S; Rao, C.G.S.N and Vemkateshwarlu, 2004-2005. DRR Technical Bulletn No.10. Pp. 47.

Ram, T., Deen, R, Gautam, S.K., Ramesh, K. Rao, Y.K and D. S. Brar, D.S. 2010 Identification of new genes for brown plant hopper resistance in rice introgressed from $O$. glaberrima and O. minuta. Rice Genetics News Letter, vol. 25, pp. 67-69

Seni, A. and Naik, V. 2017. Evaluation of Some Insecticides Against Brown Plant hopper, Nilaparvata lugens (Stål) in Rice, Oryza sativa L. International Journal of Bio-resource and Stress Management 8(2): 268-271

Shivshankar, P., Chandrashekharaiah, T, Naveena, N.L and Mallikarjun 2012. Incidence of Brown Planthopper (BPH) Nilaparvata lugens Stål (Delphacidae: Hemiptera) in relation to the age of the rice crop. Int. J. Ag. Sc. Vol III. Pp. 197-200.

\section{How to cite this article:}

Pinaki Acharjee, Chitta Ranjan Satpathi, Sanjit Pramanik and Malay Kanti Modak. 2020. Quantification of the Role of Integrated Pest Management (IPM) against Brown Planthopper Nilaparvata lugens Stål. in the Upland Rainfed Rice Growing Areas of West Bengal, India. Int.J.Curr.Microbiol.App.Sci. 9(08): 2496-2502. doi: https://doi.org/10.20546/ijcmas.2020.908.285 